\title{
INDIVIDUAL Property RIghtS ON CANADIAN INDIAN RESERVES: A REVIEW OF THE JURISPRUDENCE
}

\author{
TOM Flanagan" and Christopher AlCaNTARA ${ }^{* *}$
}

This article explores the case law on individual property righis on Canadian Indian reserves. By surveying the courts' treatment of customary holdings, Cerrificates of Possession and the procedure for valuing leasehold reserve land, the authors find that the courts have had great difficulty in interpreting those rights that have no statutory basis or off-reserve equivalent. In contrast, the courts have been much more consistent in interpreting those property rights that derive their authority from a siatute and have similarities to off-reserve legal concepts.
Cet article explore la jurisprudence en malière de droits de proprieté individuels sur les réserves indiennes canadiennes. En examinan les decisions de ta cour relativement anx terres contumieres. les certificats de possession ef la procédure relative à la valorisation des terres à bail. tes auteurs estimen que tes tribunaux ont eu beaucoup de mal $\dot{a}$ interpreter ces droits qui $n$ 'ont aucun fondement statufaire $n i$ équivalent en dehors des réserves. En revanche, les tribunaux ont été plus cohérents dans leur interpreitation des droits de propriété découlant d'un acte et présentant des similarites avec tes concepts juridiques existan à f cexterieur des réserves.

\section{TABle of Contents}

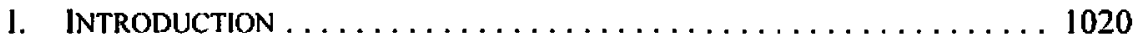

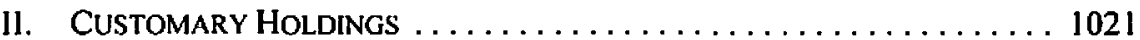

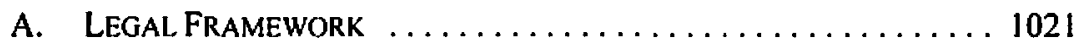

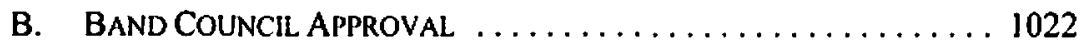

C. Customary RightS TACITLY RECOGNIZED . . . . . . . . . . . . 1023

D. CUSTOMARY RIGHTS AS INCOMPLETE

CERTIFICATES OF POSSESSION . . . . . . . . . . . . . . . . . . . 1024

11I. Certificates of Possession $\ldots \ldots \ldots \ldots \ldots \ldots \ldots \ldots \ldots \ldots \ldots \ldots \ldots$

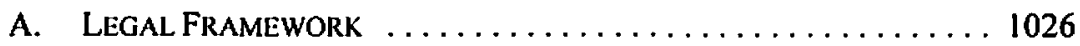

B. CERTIFICATES OF POSSESSION AND

LAWFUL POSSESSION . . . . . . . . . . . . . . . . . . . . 1027

C. Certifichte of Possession
Allotment Procedures $\ldots \ldots \ldots \ldots \ldots \ldots \ldots \ldots \ldots \ldots \ldots 1028$

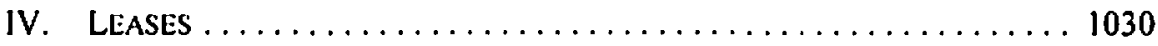

A. LEGAL FRAMEWORK ...................... 1030

B. BEFORE MUSQUEAMI. GLASS . . . . . . . . . . . . . . 1032

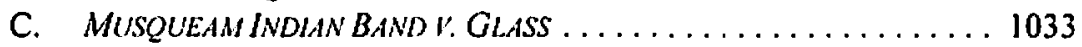

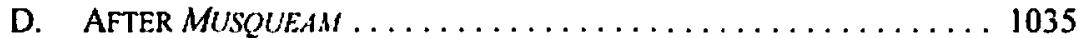

V. TRENDS IN THE INDIVIDUAL. PROPERTY

Rights CASE LAW ......................... 1036

VI. THE COMPLEXITIES OF THE INDIAN INDIVIDUAL

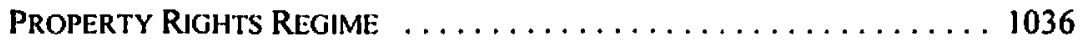

VII. ClARIFICATION OF INTERESTS $\ldots \ldots \ldots \ldots \ldots \ldots \ldots \ldots \ldots \ldots \ldots$

- Professor. Political Science. University of Calgary. Calgary. Alberta

- Ph.D. Candidate. Political Science, University of Toronto. The authors would like to thank the anonymous reviewers of the journal for their helpful comments and the Donner Canadian Foundation for its financial support of this project. 
A. BandS AND BAND COUNCILS (COLleCtivities) $\ldots \ldots \ldots \ldots, 1038$

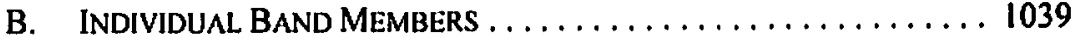

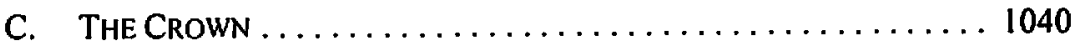

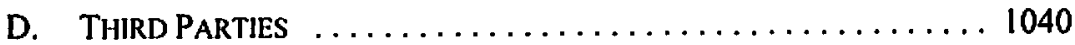

E. CONILICT AMONG THE VARIOUS INTERESTS ........... 104]

F. RANKING AND RECONCILING THE INTERESTS . . . . . . . . . . 1043

VIII. CONCLUSION .............................. 1044

\section{INTRODUCTION}

The literature on Aboriginal rights is truly a growth industry. Scholars have written extensively about treaty rights, the inherent right to self-government, cultural autonomy, indigenous difference, enhanced citizenship, indigenous law and title to traditional lands.' Very little, however, has been written on the topic of individual property rights on Indian reserves in Canada. This is regrettable because such property rights play a vital role in the economic life of First Nations. Secure, well-documented and enforceable property rights give people options for improving their economic situation. With secure title, individuals can extract resources from their land, use it as collateral for a loan to build a house or start a business, sell it for a price or lease it for a fee.

The property rights available to band members living on reserves are quite different from the property rights enjoyed by people living off reserve. According to the Indian Act, legal title to reserve land belongs to the Crown, while the land is "set apart by Her Majesty for the use and benefit of a band."2 Although these provisions allow the band as a whole to use and benefit from reserve land, the Indian $A c t$ also provides two mechanisms for individual ownership. First, ss. 20-29 of the Indian Act allow individuals to acquire lawful possession to individual tracts of land through a system of property rights called Certificates of Possession (CPs). Lawful possession, however, does not constitute fee simple ownership. Rather, a CP grants its holder a unique form of property right that has no off-reserve equivalent. For instance, a CP can only be transferred to fellow band members with the approval of the Minister of Indian Affairs and Northern Development. Second, the Indian $A c t$ allows the band and band members with individual interests in reserve land to lease their land through ss. 28(2), 38(2) and 58(3) of the Indian Act. These leases do not operate in the same way as off-reserve leases. On-reserve leases require either the assent of the band council, the consent of the entire membership and/or the approval of the Minister of Indian Affairs.

1 Michatl Asch, Home and Native Land: Aboriginal Rights and the Canadian Constitution (Toronto: Methuen, 1984); Dan Russell, A People s Dream: Aboriginal Self.Government in Canada (Vancouver: University of British Columbia Press, 2000); Taiaiake Alfred, Peace, Power. Righteousness: In Indigenous Manifesto (Don Mills: Oxford University Press, 1999); Patrick Macklem, Indigenous Difference and the Constitution of Canada (Toronto: University of Toronto Press, 2001); John Borrows. Recovering Canada: The Resurgence of Indigenous Law (Toronto: University of Toronto Press, 2002): Alan C. Cairns, Cirizens Plus: Aboriginal Peoples and she Canadian State (Vancouver: University of British Columbia Press, 2000).

: Indian Act, R.S.C. 1985, c. I-5. s. 2 
In addition, two other regimes of individual property rights exist outside of the Indian Act. First, customary or traditional holdings are tracts of land to which individuals or families have claimed usufructuary ownership based on their traditional occupation, community recognition and/or band allocation. Second, certain bands have the authority to opt out of the land management provisions of the Indian $A c t$ and create their own land management codes. These codes, created under the authority of the First Nations Land Management $\mathrm{Act}{ }^{3}$ govern all aspects of land management including leases, individual interests, resource extraction and the division of matrimonial property during divorce proceedings. So far, 31 First Nations have opted into the $F N L M A$, while dozens more have inquired.

What follows is an analysis of the case law involving customary holdings, CPs and leases. ${ }^{4}$ It draws on cases primarily from the federal and provincial lower courts, since very few cases involving individual property rights on reserves have reached the Supreme Court of Canada. These cases show that the courts have had difficulty in interpreting customary holdings, which neither derive their authority from statute nor resemble any off-reserve property rights. We conclude with a normative analysis of how the law treats the sometimes conflicting interests of band members, band councils, the Crown and third parties such as lenders.

\section{Customary Holdings}

\section{A. LEgal Framework}

"Customary" or "traditional" holdings are lands to which individual band members have acquired usufructuary rights through an allotment by a band council, recognition by the community or traditional occupation. ${ }^{5}$ A member with a customary holding can use the property for a variety of purposes, including cattle grazing, farming, housing, extracting surface resources and starting a business. However, a member's rights on customarily held land are uncertain because customary holdings do not derive their authority from statute. Rather, customary holdings exist under the band's general authority over reserve lands granted by ss. 2 and 18 of the Indian $A c t$.

Some bands (for example, the Treaty 7 First Nations in Alberta) have subdivided much of their land by customary allotments. Others have abandoned them in favour of CPs (Six Nations, Ontario), while others have a mixture of both (Cowichan Tribes, British Columbia). ${ }^{\circ}$

\section{S.C. 1999, c. 24 [FNLMA].}

- Due to its relatively recent passage, only three cases involving the FNLMA have been heard. In two of the cases, the FNLMA was only briefly mentioned in passing: Canada (A.G.) v. Wang (2001), 89 B.C.L.R. (3d) 168 (S.C.); Chapman v. Canada (2001), 89 B.C.L.R. (3d) 124 (S.C.); The third case, British Columbia Native Women's Society v. Canada (30 January 1998), Vancouver T-491-97 (F.C.T.D.), was a challenge to the Framework Agreement on First Nation Land Management (see online: First Nations Land Management Agreement <www.fafnlm.com>), which preceded the FNLMA.

3 The literature on contemporary customary holdings is quite small. See Tom Flanagan \& Christopher Alcantara, "Individual Property Rights on Canadian Indian Reserves" (2004) 29 Queens L.J. 489: Claudia Notzke, Indian Reserves in Canada: Development Programs of the Sioney and Peigan Reserves in Alberta (Marburg/Lahn: Im Selbstverlag des Geographischen Instituts der Universitat Marburg, 1985).

- Christopher Alcantara, Certificates of Possession: A Solution to the Aboriginal Housing Crisis on Canadian Indian Reserves (M.A. Thesis, University of Calgary, 2002) at 134-41 [unpublished]; Flanagan \& Alcantara, supra note 5 . 
Variation also exists in the way in which bands make allotments. Some bands (Cowichan Tribes) have never allotted land to members but have informally recognized the ownership of lands by certain families based on historical occupation. Other bands have formally allotted lands to members who have been recognized by the community as being traditional occupants (Blood Tribe, Alberta), ${ }^{7}$ while still others have abandoned the criterion of traditional occupation, preferring to rely on land use proposals (Siksika, Alberta). ${ }^{8}$ There is also great variation in how customary allotments are recorded, with some Nations documenting them in great detail (Siksika), and others relying on physical landmarks (Blood Tribe) or oral tradition (Cowichan Tribes).

Customary allotments allow bands to develop their own land management policies, which are respectful of their Nation's history and culture. They also allow bands to individually address their own specific needs. For instance, the needs of a Nation such as Siksika, which is rich in oil and gas resources, are different from the needs of Cowichan Tribes, which are more focused on surface resources and commercial developments. ${ }^{4}$ However, despite these advantages, insecurity of tenure is a major limitation on the usefulness of customary holdings. The fact that they derive their authority from the band means that politics can intrude into every aspect of their administration, including allotment, dispute resolution and expropriation. This is an even bigger problem for those First Nations with a tiny land base, a small population or a heavily connected community where politics cannot help but intrude. In such circumstances, members constantly face the threat of losing their land and any improvements they make on it. Off reserve, unjust intrusions on one's property rights can be remedied in the courts. However, the lack of a governing statute makes it difficult for reserve residents to seek such relief. Frequently, the courts decline to hear such cases; when they do, they have tended to rule in favour of disputants who have an interest in the land recognized by the Indian Act. The uncertain and sui generis nature of customary holdings has made it difficult for the courts to fashion a consistent line of jurisprudence.

\section{B. Band COUNCIL APPROVal.}

In one set of cases, the courts have ruled that customary holdings are unenforceable unless recognized by the band council. In Mathias $v$. Findlay, ${ }^{10}$ the defendant had sought permission from the band to place his trailer on a plot of unserviced, undivided reserve land. Prior to receiving the band's decision, the member began clearing trees and underbrush on the land and, after being rejected, moved his trailer onto the land anyway. The Court ruled that ss. 2(1) and 20(1)" of the Indian Act implied that the band has possession of the land unless it allots it to a member with the approval of the Minister of Indian Affairs. Since "[ $t]$ he defendant has no allotment from council[,] ... he [the defendant] is not in lawful possession of the land that he is occupying."12

- Interview of E. Fox by Christopher Alcantara (16 October 2002).

* Interview of E. Owl by Christopher Alcantara (1 October 2002).

" Ibid.: interview of L. George by Christopher Alcantara (17 April 2002).

I"' [1978] 4 W.W.R. 653 (B.C.S.C.) (Mathias].

"Section 20(1) of the Indian Act, supra note 2, reads: "No Indian is lawfully in possession of land in a reserve unless, with the approval of the Minister, possession of the land has been allotted to him by the council of the band."

1: Mathias, supra note 10 at 657 
In Leonard and the Kamloops Indian Band $v$. Gotffiedson, ${ }^{13}$ the Court decided that a customary allotment may have some force if a proper band council resolution (BCR) is passed in support of it. At issue in this case was whether the BCR was valid. Gottfriedson argued that the band council had allotted land to him through a BCR. The Court found that he did not have lawful possession, since the BCR allotting the land was unclear and illegal due to a conflict of interest. Evidence was presented showing that a proper meeting was not held, that the resolution was not properly proposed and voted on and that the BCR lacked a precise description of the allotment. In addition, the BCR was signed by the defendant, then a councilor, and his father, the chief of the band at the time. This was clearly a conflict of interest, so the allotment by the band council was ruled invalid. ${ }^{14}$

In Joe v. Findlay, ${ }^{15}$ the band had passed a BCR allotting a parcel of land to the Findlay family for two five-year terms with no renewal after the 10 th year. At the end of the second five-year term, the band ordered the family to leave the property, which they refused to do. The court affirmed Mathias, stating that absent an allotment made under s. 20(1), a member is not in lawful possession of reserve land. ${ }^{16}$ In addition, the failure of the family to pay rent during the second five-year term, and the fact that the allotment was not renewable after the 10th year, meant that the Findlay family no longer had a right to occupy the land. ${ }^{17}$

The final case in this line of jurisprudence is Heron Seismic Services Lıd. $v$. Muscowpetung Indian Band. ${ }^{18}$ Heron Seismic Services Ltd. sought permission from members of the Muscowpetung Indian Band to drill wells on their customarily held land. The members agreed, believing that government grants would pay for the work. When the grants failed to do so, the plaintiff sought the balance of the money from the individual members. The Court ruled that since the land was never formally allotted to the members, it was legally still in the hands of the band. Because the plaintiff had failed to obtain the band council's consent and the approval of the Department of Indian Affairs, the contracts were null and void. ${ }^{19}$

\section{Customary Rights TACitLY RECOGNIZED}

In a case ${ }^{20}$ dealing with the sale and purchase of reserve land, the trial division of the Federal Court of Canada took the opportunity to comment on the unique nature of individual allotments on reserves. Justice Weston stated that

it is my understanding that the band council resolution as to the rights of an individual with respect to land is sontewhat determinative... There is no doubt that reserves represent a unique form of land tenure, which for the most part defies classification under traditional property law. However it's the Court's opinion that natives

\footnotetext{
[1982] I C.N.I.R. 60 (B.C.S.C.) [Leonard].

ibid. at 70-7I.

[1987] 2 C.N.L.R. 75 (B.C.S.C.).

Ibid. al $81-82$.

Ibid. at 83.

(1990), 74 D.L.R. (4th) 308 (Sask. Q.B.) [Heron Seismic Services]

Bbid. at 313.

3.' Powless v. Sandy (1995), 95 F.T.R. 57 (F.C.T.D.).
} 
do have a common law right to bring an action for possession, but this Coun is a statutory court and there must be a specific grant of jurisdiction in order for the Court to hear [the] matter. ${ }^{21}$

Two years later, the British Columbia Court of Appeal made the strongest case for the enforceability of customary holdings in the case of George $v$. George. ${ }^{22}$ The appellant and respondent, both members of the Burrard Indian Band, were married and built a house on property allocated to the appellant by his father and uncle through customary practices. Twenty years later, the couple separated and commenced an action to determine whether "possession of real property on reserve lands, in the absence of a Certificate of Possession ... can constitute lawful possession of property under s. $20(1),{ }^{23}$ The Court ruled that although no $\mathrm{CP}$ had been issued, the appellant did have lawful possession of the property based on an undertaking supported by a BCR and signed by the Minister of Indian Affairs. Therefore, although no $\mathrm{CP}$ had been issued, the appellant was lawfully in possession of the property. ${ }^{24}$

The decision in George is important because it allows for a customary allotment to give its holder lawful possession if the requirements of s. 20(1) are met: consent of the band council and approval from the Minister of Indian Affairs. These two requirements do not have to be explicitly laid out, but can be inferred, such as in this case with the band and Ministerial support of a loan involving the property. This decision moved from recognizing customary rights with only a band council resolution to the requirement of both a band council resolution and approval of the Minister of Indian Affairs.

\section{Customary Rights as Incomplete Certificates of Possession}

In the same year that George was decided, the Federal Court of Appeal undermined the role of community recognition in determining the validity of customary holdings. In Cooper v. Tsartlip Indian Band, ${ }^{25}$ Cooper purchased a piece of customarily held property in 1942 from Henry and Lizzie Smith for a sum of $\$ 1,100$. In 1977, he made another $\$ 1,000$ payment to their son in exchange for any interest in the land. In addition, the membership generally acknowledged his ownership of the land. However, the transaction was never recorded nor was a CP ever obtained. In 1982, the Smiths' son transferred his interest in the land to the band and the transfer was approved by the Minister of Indian Affairs. The Court ruled that Cooper

could not seek a judicial declaration that he was "legally entitled to possession" of the land.... The legal status of Indian reserve lands is based on the provisions of the Indian Act... There is a possibility of acquisition by the Band member of the right of exclusive possession and use of individual parcels of reserve land, but that acquisition is strictly governed by the Indian Act. $^{26}$

$\therefore$ Ibid. at 60.61.

$\because$ [1997] 2 C.N.L.R. 62 [George].

3 lbid. at 64

is sbid. at 65, 73.

25 [1997] I C.N.L.R. 45 (F.C.A.) [Cooper].

¿ lbid. at $\mathbf{5 0}$. 
In 2000, the British Columbia Supreme Court took the opportunity to explicitly identify and analyze customary holdings in the case of Lower Nicola Bandv. Trans-Canada Displays Lid." David Shuter, a member of the band, had a customary claim to land transferred to him by George Spahan. The band challenged the validity of the transfer on the basis that the band did not recognize "traditional or customary entitlement to reserve lands outside the provisions of the Indian Act." ${ }^{28}$ Relying on the cases of Heron Seismic Services, Leonard, Joe v. Findlay and George, the Court ruled that individual customary holdings cannot receive legal recognition unless they meet the requirements of s. 20(1) of the Indian Act. ${ }^{29}$ Since Shuter had failed to obtain a valid BCR and the approval of the Minister of Indian Affairs, he did not have lawful possession of the land. "Ownership of lands based on traditional or customary use of the land does not exist independent of interests created by the Act." 30

Justice Smith implied that customary rights can exist in certain circumstances different from those of this case." The recognition of "traditional or customary use of land can, however, form the basis of granting an allotment in accordance with the Act." "'Traditional or customary allocation of reserve lands historically has been for residential or agricultural purposes and not commercial purposes." ${ }^{.33}$ This case is intriguing in that it rejects customary allotments unless they meet the requirements of s. 20(1), or if the use of such land is in line with a historical practice.

Finally, Squamish Indian Band v. Briggs ${ }^{34}$ confirmed the need for the consent of the band council and the approval of the Minister of Indian Affairs for enforceable customary holdings. At issue was whether the plaintiff or the defendant had possession of the deceased's property. The court ruled in favour of the plaintiff since she produced evidence that the band supported the transfer of the property from the original owner to her. Relying on Nicola Band and Cooper, Curtis J. decided that "a band member could not claim an individual right of possession without the consent of the Band Council and the minister specified by the [Indian] Act." ${ }^{\text {"3s }}$

It is clear that the courts have had difficulty interpreting customary allotments, first rejecting them as inconsistent with the Indian $A c t$, then opining that they may be enforceable if supported by a valid $B C R$, then holding them to be enforceable only if they meet the requirements of s. 20(1) of the Indian Act (band council consent and the approval of the Minister of Indian Affairs). Finally, in the Nicola Band case, a court departed from these precedents by stating that traditional or customary allotments that do not meet the requirements of s. 20(1) may be enforceable if the use of such land is consistent with the band's historical use of customary holdings. ${ }^{36}$ The lack of a governing statute outlining the specific nature of customary rights, the absence of an authoritative decision from the

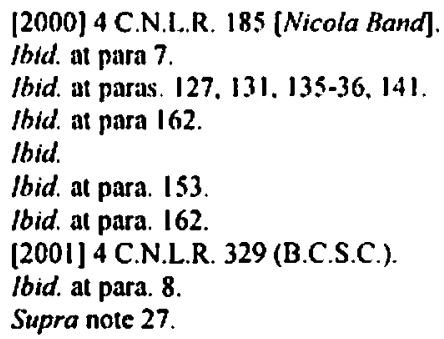


Supreme Court of Canada and the sui generis nature of such rights have made it difficult for the courts to interpret them.

\section{Certificates of Possession}

\section{A. LEgal. FRAMEWORK}

The origins of certificates of possession can be traced back to the location ticket system created under the Gradual Enfranchisement Act of $1869 .{ }^{37}$ A location ticket was proof that an individual Indian had lawful possession to a tract of reserve land. With a location ticket, a member could use the land as he saw fit, safe from legal seizure and intrusions on the land. The main restriction on location tickets was on transfers, which required band approval and could only be done with fellow band members. Govemment policymakers introduced location tickets to end Indian dependence on government rations, which they believed was rooted in their communal lifestyle. In 1951, the federal government amended the Indian ACt and replaced location tickets with certificates of possession. CPs were similar to location tickets except that the rules governing CPs were different, and the rights that flowed from them were much more comprehensive. For instance, $\mathrm{CP}$ transfers had to be approved by Indian Affairs, and members with CPs could now lease their land to band and non-band members. Certificates of possession were specifically introduced to facilitate the permanent integration of Indians into the mainstream Canadian society. ${ }^{38}$

The courts have treated certificates of possession more consistently than customary holdings. One reason for this is that CPs derive their authority from the Indian Act. According to the Indian $A c t$, a CP is evidence of a member's lawful possession of a piece of reserve property. In order to obtain a $C P$, the member must gain the consent of the band council through a valid BCR and also receive the approval of the Minister of Indian Affairs. ${ }^{39}$ If both requirements are met, the allotment is recorded in the Indian Land Registry maintained by the Department of Indian Affairs in Ottawa, and a CP is issued to the member. Once obtained, a CP provides its holder with a number of important rights. A member can sell his property, subdivide and allot portions of it to his family, ${ }^{40}$ devise it in a will, ${ }^{41}$ lease $\mathrm{it}^{42}$ build a house on it, extract surface resources from it or use it for other commercial purposes. ${ }^{43}$ At Six Nations, Ontario, members have been able to use their CPs in conjunction with band guarantees to acquire financing to build and own their own homes. ${ }^{\text {t4 }} \mathrm{At}$ Cowichan Tribes, several members with $\mathrm{CP}$-held lands gave them up to the band so that the band could

S.C. 1869, c. 6

" Christopher Alcantara, "Individual Property Rights on Canadian Indian Reserves: The Historical Emergence and Jurisprudence of Certificates of Possession" (2003) 23 Can. J. Native Studies 391 at 401 404.

"Supra note 2 , ss. 20(2)-(1).

"Ibid. s. 24.

"Ibid. ss. 42-46.

$\because$ lbid., s. $58(3)$.

" Ibid., s. 20(1).

"In conjunction with a band guarantec, a CP allows a band member to get around the seizure for debt restrictions outlined in Ss. 29 and 89 of the Indian Act, ibid. See supra note 6 and Christopher Alcantara, "Certificates of Possession and First Nations Housing: A Case Study of the Six Nations Housing Program" 1. of Aboriginal Economic Development [forthcoming in 2005] 
lease the property to a company to develop the Wal-Mart and Duncan Mall in downtown Duncan, British Columbia. In exchange for doing so, the members receive approximately ten percent of the land rent paid to the band by the lessees. ${ }^{\text {ts }}$

A CP, however, does not give its holder fee simple title to reserve land. Title remains with the Crown, the land remains reserve land as defined under s. 2(1) of the Indian Act, and certain transactions involving $\mathrm{CP}$ land are restricted. For instance, although a member may sell or transfer his land, the Indian $A C l$ limits customers and recipients to fellow band members. Even then, the Minister of Indian Affairs must approve the transfer. ${ }^{\text {to }}$ This also applies to wills involving CP-held land, where approval of the Minister is necessary before wills take legal force. ${ }^{47}$ Although CPs do not give their holders fee simple ownership over reserve land, they do provide them with greater security of tenure than customary holdings because the courts have been consistent in upholding lawfully issued CPs and the procedures for administering them under ss. 20(1) and 24.

\section{B. Chrtificates of Possession and Lawful Possession}

The courts have been consistent in defining and upholding the principle of "lawful possession" listed under s. 20(1) of the Indian Act. Although a CP does not have to be issued in order for a member to have lawful possession, the presence of a valid $C P$ strengthens the holder's claim. In the case of Pronovost v. Canada (Minister of Indian and Northern Affairs), Marceau J. observed:

The Act speaks of a right of "possession" which must be proven by a Certificate of Possession, taking the place of a real estate title: it speaks of a right which does not derive from that of an owner but which may nonetheless be transferred as such, both by imer vivos and mortis causa, alihough such a transfer can only be fully effective after it has been approved by the Minister; and this hybrid right, which is both patrimonial and personal, is applied formally to the land by the Act without specifying what becomes of buildings or improvements on the land. It has been called a sui generis right: that is undoubtedly truc, but whal I wish to emphasize here is that this sui generis right defies any rational classification under our Iraditional property law: ${ }^{\text {t3 }}$

Master Breitkreuz of the Queen's Bench of Alberta agreed, stating in Dale v. Paul:

The portions of the Indian Act that were provided to me show that there is a system of landholding among the Indian population who live on a reserve that requires the approval of the Minister of Indian and Northern Afrairs and the Council of the Band in question. The evidence is unassailable that the applicant has the lighest form of title an Indian can have to land that is part of an Indian reserve. It appears to me in fact that a certificate of possession is very close for all practical purposes to a fee simple certificate of lille. ${ }^{40}$

The idea that CPs are "the highest form of title an Indian can lave to land that is part of an Indian reserve" was confirmed in several other cases. In Westhank Indian Band v.

4s Flanagan \& Alcantara, supra note 5.

4" Supra note 2 at s. 24.

4) Ibid., ss. 45-46.

4* [1985] I F.C. 517 al 523-24 (F.C.A.).

" $2000 \mathrm{ABQB} 411$ at para. 9. 
Normand,,$^{50}$ the band brought a suit against the defendant on behalf of Gary Swite, band member, who held a CP to land damaged by floodwater. The Court ruled that Gary Swite should have brought the action rather than the band, since he was the $\mathrm{CP}$ holder. According to Drossos J., a CP issued by the Crown with the consent of the band invests in its holder "all the incidents of ownership ... with the exception of the legal title to the land itself, which remains with the Crown." In In support of this conclusion, Drossos J. cited the precedents of Joe v. Findlay ${ }^{52}$ and Brick Cartage Lid. v. Canada, ${ }^{53}$ which held that land allotted to a band member by the band through a valid BCR and approved by the Minister of Indian Affairs invests in its holder all incidents of ownership.

The finding that a CP invests in its holder all incidents of ownership except legal title was affirmed in two subsequent cases. In the case of Simpson v. Ryan,,$^{54}$ the Court was asked to determine if band council approval was necessary for a transfer of a CP. Justice Dubé ruled that the consent of the band is not required, since s. 24 of the Indian Act, described in greater detail below, only requires the approval of the Minister of Indian Affairs. In addition, band council approval was unnecessary because the $\mathrm{CP}$ holder is "vested with all the incidence of ownership with the exception of the legal title." Watts $v$. Doolan affirmed the strength of CPs by upholding the holder's right against trespass by the band.$^{30}$ Without the defendant's permission, the band placed a radio antenna, two satellite dishes and a wooden frame building on Marlon Watts' CP-held land. The Court ruled that the band had trespassed on his land and therefore had to pay him $\$ 10,300$ in damages and $\$ 5,281.95$ in costs. The Court also allowed $\mathrm{Mr}$. Watts to pursue further action against the band unless a new agreement was made for rent or the band removed all of the items that it had placed on the land. ${ }^{57}$

\section{Certificate of Possession allotment Procedures}

The courts have also been consistent in upholding the statutory requirements for allotting and transferring CPs. As described in the section on customary holdings, Mathias, Cooper, George and Nicola Band confirmed that a band member can only gain lawful possession to a tract of reserve land through a valid BCR and approval from the Minister of Indian Affairs. ${ }^{58}$ The courts have also held that $\mathrm{CP}$ allotment procedures must be fair. The case of Campbell $v$. Elliot ${ }^{59} \mathrm{grew}$ out of a dispute between band members over an allotment of land. Without informing the applicants or their legal counsel, the band council met and confirmed the allotment of the land to Frank and Amelia Wilson, members of the Cowichan Tribe Indian Band. The Court ruled that "an administrative authority charged with the responsibility of making decisions affecting the legal rights and interests of persons within the reach of its decision-making processes is under a general duty of procedural fairness to

\footnotetext{
[1994] 3 C.N.L.R. 197 (B.C.S.C.).

lbid. at 199.

[1981] 3 C.N.L.R. 58 at 60 (B.C.C.A.) [Joe].

[1965] I Ex. C.R. 102.

(1996), 106 F.T.R. 158 (IF.C.T.D.) [Simpson].

Ihid. at 160 .

(2000), 187 F.T.R. 83 (F.C.T.D.).

lbid. at paras. 8, 21 .

See also Joe, supra note 52; Hupacasath First Nation v. Sayers, 2001 BCSC 699.

[1988] 4 C.N.L.R. 45 (F.C.T.D.).
} 
afford those persons a fair hearing." ${ }^{\circ 0}$ This was confirmed in Leonard, where the Court ruled that a proper BCR allotting land must include a clear recording of the minutes, a description of land involved and a record of the call and results of the vote. in addition, any chiefs and councilors who may have a potential conflict of interest must not be involved in the allotment process. $^{61}$

The courts have also been consistent in upholding the statutory requirements for transferring CP-held land. Section 24 of the Indian Act reads:

[A]n Indian who is lawfully in possession of lands in a reserve nay transfier to llie band or another member of the band the right to possession of the land, but no transfer or agreement for the transfer of the right to possession of lands in a reserve is effective until it is approved by the Minister.

Simpson v. Ziprick ${ }^{62}$ laid out the basic rules for transferring CP-held land. In a decision examining whether the Ontario Partition $A c t^{63}$ or $\mathrm{s} .24$ of the Indian Act was controlling in determining the proper division of on-reserve matrimonial property, ${ }^{\text {th }}$ the Court ruled that $s$. 24 was determinative since jurisdiction over Indians belongs to Parliament. According to Hamilton J., "[b]y virtue of s. 24 of the Indian Act he [the band member with the CP] may transfer only to the band or to another member of the band, but no transfer is effective until it is approved by the Minister of Indian Affairs and Northern Development." 6 s.

A further confirmation of the necessity of Ministerial approval for $\mathrm{CP}$ transfers was made in Simpson v. Ryan. ${ }^{66}$ In that case, the Court was asked to determine whether a particular transfer had met the requirements of s. 24 of the Indian Act. The plaintiff argued that although the transfer had met the one requirement listed under s. 24, that being the approval of the Minister of Indian Affairs, the transfer was not valid because the band had never consented to it via a BCR. The Court disagreed, stating that under $\mathbf{5 .} 24$ "there is no explicit or implicit requirement for a Band Council resolution in respect of any such transfer. The Band's interest in land which has already been allotted to an individual band member has disappeared or is at least suspended." ${ }^{67}$

One month later, the trial division of the Federal Court of Canada had another opportunity to interpret s. 24 of the Indian Act. In Jones Estate v. Louis, ${ }^{68}$ the plaintiff (AEJ) agreed to transfer her CP-held land to the defendant (HL). In exchange, HL agreed to purchase AEJ's farm equipment. Two years later, AEJ decided she did not want to transfer her land to $\mathrm{HL}$ because HL did not purchase the farm equipment. The Court ruled that the transfer was not

(a) Ibid. at 52 .

"1) Supra note 13 at 70-71.

1.2 (199S), 126 D.1.R. (41h) 754 (B.C.S.C.) [Ziprick]

"R.S.O. 1990, c. P-4.

a See also Sandy v. Sandy (1979), 27 O.R. (2d) 248 (C.A); Greyeyes v. Greyejes, |1983] I C.N.L.R. S (Sask. Q.B.) [Greyejes]; Laforme v. Laforme, [1984] 2 C.N.L.R. 88 (Ont. Co. C1.): Derrickson 1. Derrickson, [1986] 1 S.C.R. 285 [Derrickson]; Paul v. Paw, [1986] I S.C.R. 306: Panl v. Kingsclear Indian Band (1997), 137 F.T.R. 268 (F.C.T.D.).

is Ziprick, supra note 62 at 758.

(*) Supra note 54.

i.) Ibid. at 160.

e.x [1996] 3 C.N.L.R. 85 (F.C.T.D.). 
valid despite a signed document entitled "Transfer of Land on Reserve" that had been submitted to and approved by the Band. Justice MacKay reasoned that the approval of the band was irrelevant because $s .24$ does not require it. Rather, the approval of the Minister of Indian Affairs was determinative. ${ }^{69}$

In Milliken v. Canada (Minister of Indian Affairs and Northern Development),${ }^{70}$ three members of the Kettle and Stoney Point First Nation were joint tenant owners of a tract of reserve land. Two of them wanted to sever the tenancy but the third member did not. Up until 1997, the Department of Indian Affairs had a policy of opposing the severing of all joint tenancies unless all members agreed. The Court ruled that it would not interfere in the decision of the Minister.

The principle of Ministerial deference was also affirmed in Batchewana First Nation of Ojibways v. Corbière." John Corbière had a CP to two parcels of land on the Batchewana Reserve, which he transferred to his three children as tenants in common. By 1998. he had amassed an outstanding balance of $\$ 26,899.90$ with the band. The band challenged the transfer in court, arguing that the band should have lawful possession of the property in order to force collection of Mr. Corbière's owed monies. ${ }^{22}$ The court ruled that the original transfer was valid, because it was approved by the Minister, it was listed in the registry, and new CPs had been issued to the three children. ${ }^{73}$ The band council could not invalidate a transfer lawfully approved by the Minister. ${ }^{74}$

\section{LEASES}

\section{A. Legal Framework}

There are four types of on-reserve leasing arrangements in Canada: s. 28(2) permits, s. 38(2) designations, s. 58(3) leases and informal leases called "buckshee" leases. Under s. 28(2), the band, on behalf of a member with a customary allotment or CP-held land, can obtain a permit from the Minister of Indian Affairs to allow a non-band member to farm or graze animals on the member's land. Section 28(2) reads: "The Minister may by permit in writing authorize any person for a period not exceeding one year, or with the consent of the council of the band for any longer period, to occupy or use a reserve or to reside or otherwise exercise rights on a reserve." ${ }^{\text {"I }}$ In exchange, the off-reserve farmer or herder pays the member

Ibid. at 96; see also Mallowry v: Tzeachen Indian Band (1987). 17 F.T.R. 196 (F.C.T.D.).

[1997] F.C.J. No. 482 (F.C.T.D.) (QL).

(2000), 198 F.T.R. 36 (F.C.T.D.).

Ibid. at paras. 4, 6.14.

Ibid. at para. 42.

The courts have also upheld the statutory requirement of Ministerial approval for wills involving CP-held land. See Johnson v. Pelke) (1997), 36 B.C.L.R. (3d) 40 (S.C.): Undenwood Estate v. Clarron (3 December 1997), Vancouver C970087 (B.C.S.C.); Francis v. Canada (Minister of Indian and Northern Affairs), [2000] 4 C.N.L.R. 99 (F.C.T.D.); Morin v. Enoch Band of the Stony Plain Indian Reserve (II February 2000) Ottawa T-1493-99 (F.C.T.D.); Okanagan Indian Band v. Bonneau. [2002] 4 C.N.L.R. 155 (B.C.S.C.); Okanagan Indian Band v. Bonneau, [2003] 3 C.N.L.R. 160 (B.C.C.A.).

is Indian Act, supra note 2, s. 28(2). 
a rental fee ranging anywhere from $\$ 1$ to $\$ 43$ an acre. ${ }^{76}$ At the time of expiry, it can be renewed with a new or the same rental fee, or allowed to expire. Permits typically have a term of one to five years, although theoretically they can be of any length and renewed without limit. ${ }^{7 n}$ In addition, the permit can be cancelled at any time, although there must be sufficient cause. $^{78}$

The second type is a personal lease, which members with CPs can obtain directly from the Minister of Indian Affairs. Under s. 58(3), "The Minister may lease for the benefit of any Indian, on application of that Indian for that purpose, the land of which the Indian is lawfully in possession without the land being designated." Department of Indian Affairs and Northern Development's (DIAND) policy is that leases with a term of over 49 years must be approved "by a majority of electors present at a meeting called to discuss the proposed leasing arrangement." ${ }^{80}$ For terms less than 49 years, DIAND usually seeks band council approval, although the Minister can still approve the lease regardless of band council opposition. ${ }^{81}$ Tsartlip Indian Band v. Canada (Minister of Indian Affairs and Northern Development) held that although there is no statutory requirement for band council approval, "[t]he more a lease operates to the substantial detriment of the band as a whole the more the Minister must pay attention to the concerns expressed by the band." Minister continues to have considerable discretion over whether or not to grant a $5.58(3)$ lease.

The third type of lease allows the band to designate band land for leasing. Section 38(2) provides that "[a] band may, conditionally or unconditionally, designate, by way of a surrender to Her Majesty that is not absolute, any right or interest of the band and its members in all or part of a reserve, for the purpose of its being leased or a right or interest therein being granted." 83 In order for a designation to occur, it must be made to the Crown, accepted by a majority of the band's membership and affirmed by the Governor in Council. ${ }^{8 \cdot 4}$ Once these requirements have been met, the federal government can lease the land to the band or development company, which can then obtain financing to develop the land. Typically, land is designated for a term between 49 to 99 years, depending on the band and the nature of the development.

The final type of lease is the "buckshee" lease, an unregistered lease made between a band member with an interest in land and a lessee. Buckshee leases are used for a variety of purposes including farming and grazing by off-reserve farmers and erecting advertising

76. Supra note 8; interview of Piikani Nation Lands Committec by Christopher Alcantara (26 September 2002).

" James I. Reynolds, "Acquiring Interests in Reserve Land," (Vancouver: The Continuing Legal Education Society of British Columbia, 2002) online: Cl.E Practice Desk <www.cle.bc.ca/Cle/Practice+Desk/ Practice+Articles/Collection/03-app-acquiringreserve>.

"Hofer v. Canada, 2002 FCT 16.

"Indian det, supra note 2, s. $58(3)$.

Rit Reynolds. supra note 77 at 6.

${ }^{81}$ lbid.

*2 [2000] 2 F.C. 314 at para. 57 (F.C.A.)|Tsarthp]

*I Indian ACt, supra note 2, s. 38(2).

*4 Opetchesaht Indian Band v. Canada. [1997] 2 S.C.R. 119: St. Ann's/sland Shooting \& Fishing ('Tuh v Canada. [1950] S.C.R. 211. 
billboards along major highways. All of the revenue for such leases goes directly to the band member. The band does not reap any revenue from buckshee leases and they are not enforceable in court. ${ }^{85}$

The sui generis nature of land tenure on reserves has presented challenges to Canadian courts in interpreting leases. The most serious problem has been how to determine the "land value" of leasehold reserve land. Disputants have used a variety of methods, including negotiation and mediation, to end disputes. However, the method with the largest impact has been litigation. The following cases illustrate how, despite the lack of a governing statute, the courts have fashioned a somewhat consistent line of legal doctrine regarding the value of leasehold reserve land.

\section{B. BEFORE MUSQUEAM V. GLASS}

In Leighton v. Canada, ${ }^{86}$ the Court was asked to interpret the meaning of "the amount which is ... in the opinion of the Minister a fair market rent for the land leased on the terms and conditions contained in this lease." ${ }^{87}$ The land in question was reserve land leased for a term of 25 years with a rent review provision operating every five years. The Minister, acting on the advice of the band, imposed a flat $\$ 720$ per year increase on 115 of the 119 lots, which was contested by the lessees. The Court ruled that the flat increase was unfair since the lots had a wide variation in value. ${ }^{88}$ In addition, the Court observed that reserve leased land cannot be appraised by comparing it to its value in the open market. Rather, "[t]he only applicable method of valuation is the Market Data Approach and the only truly applicable data is market rental data on other Indian leases as the lease calls for the following terms which are unique. ${ }^{\text {"99 }}$ Furthermore, the unique nature of Indian land, including the power of the Minister over such lands, requires that the valuation of land be conducted by comparing such lands to leasehold reserve lands that have "identical or similar terms and conditions."

This decision was confirmed by the trial division of the Federal Court of Canada in Golden Acres Lid. v. Canada." At issue was how to determine the "market value" of Indian leased land for the purpose of adjusting rent according to a five-year rent review provision in the lease. Relying on Leighton"2 and the Supreme Court of Canada's characterization in R. v. Guerin' of Indian land tenure as being generally inalienable, the Court ruled that "there can be no pretext here that such [leasehold reserve] property is comparable to real estate in the free and open market." ${ }^{.4}$ Indeed, the inalienability of reserve land means that a lessee

ns Interview of Emil Owl Child, Land Manager, Siska First Nation, Alberta by Christopher Alcantara (1 October 2002); Interview of Fran Wilgress, Land Manager and Chair of the Land Management Committce, Cowichan Tribes, British Columbia by Christopher Alcantara. (16 April 2002); Nicola Band, supra note 27.

M. (1987), 13 F.T.R. 198 (F.C.T.D.) [Leighton].

"l ibid. al 202.

at Ibid. at 203.

*) Ibid. at 205 [emphasis in original]

"lbid. at 205-206.

(1988), 22 F.T.R. 123 (F.C.T.D.).

Supra note 86

[1984] 2 S.C.R. 335.

Supra note 91 at 126. 
cannot hold freehold title even if the lease says otherwise. "The lease's notion of 'market value' (clause $l(e)$ ) therefore, in both law and equity, must be construed as meaning the value of land in that very restricted 'market' comprising comparable Indian lands, for that is the market reality."

The Federal Court of Canada continued to build on its earlier decisions with its judgments in Rodgers v. Canada (Minister of Indian Affairs and Northern Development) and Devil's Gap Cottages (1982) Lid. v. Canada. ${ }^{\%}$ In these two cases, the leases specified that the value of reserve land had to be calculated by comparing them to similar land off reserve. In both cases, the Court ruled that such a requirement was enforceable, as long as clear language to that effect was used and agreed to by all of the parties in the lease. ${ }^{97}$

In 1998, the Federal Court of Canada had another opportunity to review a rent calculation provision in a lease involving reserve land. In St. Martin v. Canada (Minister of Indian Affairs and Northern Development), ${ }^{98}$ the leases had a term of 21 years with rent review every seven years. New rent was to be calculated "by applying the current prime lending factor of the Bank of Canada to the said market value of the land." The market value of the land was to take into account "the value of other demised lands in the area" but not any improvements made on the land. ${ }^{100}$ The Court ruled that the process for determining the new rent was as follows: "estimate the fee simple market value of the subject sites, reduce this value by a percentage which reflects the difference between fee simple interest and the interests inherent in the demised lands, and, apply a market oriented interest rate to arrive at [a] fair market rent." 101 Based on that criterion, the discount factor was 40 percent.

\section{MUSQUEAM INDIAN BAND V. GLASS}

In 2000, the Supreme Court of Canada issued its own opinion on the proper method of valuing reserve land. In Musqueam Indian Band v. Glass, ${ }^{102}$ the band had surrendered approximately 40 acres of reserve land for leasing. Several years later, the Crown gave a head lease to a company that serviced and subdivided the land into residential lots. The company then issued 99-year subleases to individuals to build houses on the land. An initial rental rate was established for the first 30 years. Rent review was to occur after the first 30 years and every 20 years after that. The rent review clause mandated that rent would be six percent of the "current land value" of the lots. The Supreme Court of Canada was asked to determine what "current land value" meant. The Court split 5-4 on the issue with the majority judgment by Gonthier J. (supported by Major, Binnie and LeBel JJ.), a concurrence from Bastarache J., and a dissenting opinion from McLachlin C.J.C. (supported by L'HeureuxDubé, lacobucci and Arbour JJ.). Eight of the Justices (Bastarache J. dissenting) agreed that

\footnotetext{
Ibid. at 127-28.

(1993). 74 IF.T.R. 164 (F.C.T.D.): [1991] F.C.J. No. I 142 (F.C.T.D.) (QI.)

See Musqueam Indian Band v. Glass, [2000] 2 S.C.R. 633 at paras 18, 42, 68 [1/usqueam].

(2001). 43 R.P.R. (3d) I (F.C.A.) [St. Marin).

"Ibid. at para 3.

Iui Ibid. at para 5.

I11) St. Martin v. Canada (Minister of Indian Affairs and Northern Development), [2001] F.C.J. No. 1032 at para. 69 (F.C.T.D.) (QL)

iin Supra nole 97.
} 
leasehold reserve values should be determined by treating them as freehold or fee simple interests unless the lease specifically states that the land should be treated as a leasehold interest, such as in the case of Leighton, described above. Indeed, absent such a clause, "land" and "value" must mean the "exchange value" rather than the "use value" of the land to the lessee. ${ }^{.03}$

The disagreement among the Justices was over the imposition of a discount on the land value of reserve land. The majority argued that the determination of "current land value" must take into account the

Iegal restrictions on the land and market conditions. One cannot simply assume that either legal restrictions or market conditions are the same for reserve land as for off-reserve land. In fact, the legal restrictions on the reserve land differ from those on the comparable areas of Vancouver. So too the market may respond differently to Musqueam reserve land than it does to land off the reserve. ${ }^{104}$

Land value may increase or decrease, depending on the legal restrictions and market conditions of a particular reserve. ${ }^{105}$

In this case, the trial judge applied a 50 percent discount on the Musqueam Park leases. The 50 percent discount was determined by examining the sale prices of the Salish Park leases, a similar set of pre-paid leases on the Musqueam reserve. "Because the leasehold and reserve features are similar for Salish Park and for Musqueam Park, the trial judge found that the 50 percent rate was transportable, and applied it to the Musqueam comparables." 106 This application of a 50 percent discount was affirmed by a majority of Supreme Court of Canada Justices, who agreed with the trial judge's determination that the "uncertainty related to property taxation, publicized unrest, and limitations on non-natives' entitlement to stand for election to the reserve's governing body" reduced the value of Musqueam Park leasehold land..$^{107}$

The minority disagreed with the application of any discount or markup based on the legal restrictions of the land, arguing that calculating "current land value" meant determining "the 'highest and best use' for the land that is legally permissible, disregarding any restrictions imposed by the lease itself."108 Using the surrender process, the band could legally sell the land to anyone for fair market value. Therefore, any reduction in value based on potential legal restrictions inherent in reserve land would be inappropriate.

Iin Ibid. at paras. 9.38 .

I'4 Ihid. at para 46; see also Jonathan R. Kesselman, "Aboriginal Taxation of Non-Aboriginal Residents: Representation, Discrimination, and Accountability in the Context of First Nations Autonomy" (2000) 48 Can. Tax J. 1525.

i'is Supra note 97 at para. 48.

iks Ibid. al para. 51.

I'"' Ibid. al paras. 7, 53 .

III ibid at para. 13. 


\section{AFTER MUSQUEAM}

Immediately after the decision, Native leaders and commentators were initially critical of the Musqueam decision, predicting that it would lead to a devaluation of reserve land. ${ }^{109}$ However, beyond its chilling effect on some reserves, such as initially at Westbank First Nation in British Columbia, ${ }^{10}$ the Musqueam decision has not led to an automatic devaluing of reserve land. In the following case, the discount was rejected and a new trial was ordered to determine the precise effect of the legal environment of the particular reserve on the value of the lands in question. In 2001, the Federal Court of Appeal was asked to review the 1998 St. Martin decision described above."' The appellants did not dispute the trial judge's determination of the fair market value of the lands in question. However, they did contest his application of a 40 percent discount factor. The Court of Appeal ruled that the trial judge had erred in accepting the appellant's appraiser's determination since the appraiser had applied the discount based on the value of the land as a leasehold interest, a principle rejected by the Supreme Court of Canada in the Musqueam decision. Therefore, the Court ordered a new trial to determine the fee simple value of the land and the effect of the particular legal environment of the Whitefish reserve on the market value of the lands in question. ${ }^{112}$

In Morin v. Canada, ${ }^{1 / 3}$ the Federal Court applied an increase in the value of leasehold reserve land based on the fact that one appraiser tried to familiarize himself with and apply the principles of the Musqueam decision in his appraisal. In that case, the rent review provision of the leases called for a new calculation of rent every five years based on the fair market value of the land adjusted by the average lending rate established by the Bank of Canada. The determination of the fair market value of the land had to take into account the value of other demised lands in the area but should not take into account any improvements made to the land by the lessees. The Crown's appraiser, Mr. Duncan Bell, found that the fair market value of a typical lot had been $\$ 42,000$ in 1994 and $\$ 51,500$ in 1999. The lessees' appraiser, Mr. Peter Rueck, found the values to be $\$ 19,200$ in 1994 and $\$ 24,000$ in 1999. The Court preferred Mr. Bell's appraisal because he had taken

great pains to understand and to apply the principles establisled in Musqueam with respect to the determination of the fair market value of Indian reserve land surrendered for leasing purposes... In contrast. Mr. Rueck testified in cross-examination that: I didn'1 go through the Mfusqueum decision in great detail. I used it just as a very preliminary guide as an indication that there is a difierence between the two types of properties [freehold and leaseloold]. ${ }^{1 / 4}$

Mr. Rueck had treated the land as a leasehold interest. a principle rejected by the Supreme Court of Canada. ${ }^{115}$ Therefore, the Court ruled in favour of Mr. Bell's appraisal, since it had

l"w Janice Tribbetts. "Native lands ruled less valuable" Windsor Stur (10 November 2000) BI2: Jeff I.ec. "Court ruling favours Musqueam leaseholders" I'ancouver Sim (10 November 2000) A!

111) Flanagan \& Alcantara, stupra note 5 at 524-25.

III Sec supra note 98 and accompanying text.

II: Alusqueam, supra nole 97 at $9,11-13$.

113 (2002), 226 F.T.R. 188 (I:C.T.D.).

iIs Ibid. at para. 67 .

11' lbid. al paras. 68-69. 
treated the lands as fee simple estates and had compared them to similar demised lands on the reserve to arrive at a final land value.

\section{Trends in the Individual Property Rights Case Law}

Several important trends can be gleaned from the case law on individual land tenure on reserves. For customary holdings, the courts have had great difficulty developing a consistent line of jurisprudence because customary holdings do not derive their authority from a statute. The uncertain nature of customary holdings makes it difficult for the courts to determine what constitutes a legally enforceable interest. To answer this question, the courts eventually turned to the only statute dealing with individual land tenure on reserves: the Indian Act. At first, they found that a customary holding was only enforceable if it had the consent of the band council. Later, they adopted all the requirements laid out in s. 20(1) of the Indian Act, namely the consent of the band council and the approval of the Minister of Indian Affairs. In short, a customary holding is only enforceable if it resembles an incomplete CP.

In contrast, the courts have treated CPs in a much more consistent manner right from the beginning. The courts have upheld the necessity of the consent of the band council and/or the Minister of Indian Affairs for allotting and transferring of CP-held land. They have affirmed that CPs are a sui generis statutory property right and that they are the highest form of title an individual band member can have to reserve land. Furthermore, $C P s$ provide their holders with security of tenure and are enforceable against the band, fellow band members and nonband members. The consistency of the CP case law can be attributed to the Indian Act, where $\mathrm{CPs}$ are explained and defined in great detail. Indeed, the certain nature of CPs has made it easier for the courts to interpret them in comparison to customary holdings.

The courts have also been consistent in their treatment of how leasehold interests on reserve land are valued for the purpose of rent calculation. They have relied on precedents holding that Indian land tenure is sui generis and on the Indian $A C l$, which has authority over all leases involving reserve land. Further strengthening this consistency was a Supreme Court of Canada decision affirming the jurisprudence established by the lower courts. The result is a consistent line of jurisprudence holding that "fair market value," or "market value," or "current land value" of leasehold reserve land requires the appraiser to treat the land as a freehold rather than a leasehold estate, unless the lease states otherwise. In addition, an increase or decrease in value may be applicable depending on the legal environment of the particular reserve.

\section{THE COMPLEXITIES OF THE INDIAN INDIVIDUAL. PROPERTY RIGITS REGIME.}

Overall, the above jurisprudence only scratches the surface of the complex nature of individual property rights on Canadian Indian reserves. Two problems in particular, the division of matrimonial property and the restrictions on Indian property as collateral for obtaining off-reserve financing, demonstrate some of the additional difficulties that practitioners, administrators and other interested parties face beyond the ones described above, when dealing with on-reserve property rights. 
One major problem caused by the individual property rights regime on reserves is the harm inflicted on women during the division of matrimonial property proceedings. In essence, the courts have been hampered by the individual property rights regime on reserves in crafting equitable settlements between divorce disputants. The lack of relevant bandcreated or Indian Act provisions has prevented the courts from equally dividing matrimonial reserve property between two divorcing disputants. Rather, the courts have been restricted to awarding sole ownership of matrimonial property to whoever is listed as holder of said property, despite the monetary or other contributions of the other spouse to that property. ${ }^{116}$ The courts have, however, ruled that the individual property rights regime on reserves does allow it to award monetary compensation to the other spouse in lieu of an interest in the matrimonial property. ${ }^{117}$

A second additional problem with individual property rights on reserves involves the restrictions on seizure for debt found in ss. 29 and 89 of the Indian Act. Section 29 reads that "[r]eserve lands are not subject to seizure under legal process" while s. 89(1) states "[s]ubject to this Act, the real and personal property of an Indian or band situated on a reserve is not subject to charge, pledge, mortgage, attachment, levy, seizure, distress and execution in favour or at the instance of any person other than an Indian or band." In essence, these two sections prevent Indian entrepreneurs and bands from using their on-reserve real and personal property as collateral to secure financing for starting a business, building a house or pursuing a different economic development project. Without some sort of security, off-reserve financiers are hesitant to provide financing since they have no way of recouping their losses in the event of a default on a loan.

The legality of these restrictions on seizure for debt was confirmed in a number of legal decisions. In 1977, the Ontario Supreme Court ruled that s. 89(1) prevents the encumbrance or alienation of reserve land by and in favour of a non-Indian. ${ }^{118}$ The Alberta Court of Queen's Bench agreed in 1989, stating that 5. 89(1) must be interpreted as to protect band and status-Indian property when a charge, attachment or levy is not in their favour. ${ }^{119}$ Besides land, the courts have also ruled that real property (in other words, housing), ${ }^{120}$ personal property (in other words, a bus) ${ }^{121}$ and money (in other words, a pay cheque or band funds received from the Crown) ${ }^{122}$ situated on reserve is protected by s. $89(1)$ and therefore cannot be used as a collateral for a loan. ${ }^{123}$

116. See Sandy v. Sandy (1979), 25 O.R. (2d) 192 (Ont. Div. C1.): Grejeyes, supra notc 64: Pine v. Pine (1996), 24 O.T.C. 321 (Ont. Div. C1.): Baptiste i: Baptiste, [1987] B.C.J No. 1146 (B.C.S.C.) (QL).

1 "Derrickson, supra note 64; Standing v. Standing (1991), 85 D. L.R. (4th) 309 (Sask. Q. B.): George, supra note 22. For further information on this issuc, see Christopher Alcantara, "Indian Women and the Division of Matrimonial Real Properly on Canadian Indian Reserves" (2005) [unpublished] [Alcantara. "Indian Women"].

II" Re Bell and Bell (1977), 16 OR (2d) 197|Bell]

119 Potss v. Potts (1988). 91 A.R. 161.

15" Bell, supra note 118.

I3I Mitchell v. Sandy Bay Indian Band (1983), 22 Man. R. (2d) 286 (Q.B.)

I:: R. v. Nowegijick, [1983] I S.C.R. 29: Fajerman Brothers Lid. v. Peter Ballantyne Indian Band, [1986] I C.N.L.R. 6 (Sask. Q.B.). Fricke and Seaton Timber Led. v. Moricetown Indian Band, [1988] I C.N.L.R. 11 (B.C.S.C.).

13" Wahpeton Dakota First Nation v. Lajeunesse, [2002] 3 C.N.L.R. 285 (Sask. C.A.). 
Although the above case law indicates that reserve property is protected against seizure for debt, the courts have allowed for some exceptions in certain instances. For example, the courts have confirmed that Indians or bands can seize Indian property in the event of a default. In the case of Hopkins v. Hopkins, ${ }^{124}$ the Court ruled that s. 89(1) does not apply to the division of matrimonial property in the event of a divorce since Indians or bands can seize property from each other in the case of default or garnishment. In Bellegarde $v$. Walker, ${ }^{125}$ the Court decided that the garnishment of the Indian husband's wages for child support was legal since the garnishor in this case was the Indian wife. The case of Shubenacadie Indian Band $v$. Francis ${ }^{126}$ affirmed the ability of Indian individuals and bands to seize monies and assets in the event of a default by an Indian on-reserve. In addition to these exceptions, $s$. 89 (1) does not protect a limited company from seizure, nor does it protect the personal property of an incorporated hand council or company. Conversely, an unincorporated council or business is protected from seizure and garnishment. ${ }^{127}$ The above case law is important as some First Nations have been able to use the case law to bypass ss. 29 and 89 to secure offreserve financing for the various projects of their individual members. ${ }^{1.8}$

\section{Clarification of Interests}

Taken as a whole, the above jurisprudence points to a highly complex legal environment. This makes it difficult for actors with interests in on-reserve property to effectively structure their transactions to achieve particular goals. The following section explores the interests of four actors on reserves in Canada: bands and band councils (collectivities), individual band members (individuals), the Crown (as legal owner, intermediary and fidicuary) and interested third parties (such as banks and off-reserve home occupants). It looks at how each actor should seek to structure its transactions to achieve its particular ends and how the law should rank and reconcile these various, sometimes competing, interests.

\section{A. Bands and Band Councils (Collectivities)}

For the majority of bands and band councils in Canada, the ideal goal with respect to reserve land is to use it for the benefit of the entire reserve. Land is to be used for achieving the collective interests of the band as opposed to a select few individual band members benefiting from the land. ${ }^{129}$ Of the three types of property regimes looked at in this paper, customary rights provide the most efficient and effective means for achieving a band or band council's collective goals. Under this regime, the band and band council hold ultimate authority over the entire land holdings of the reserve. They have the legal authority to allot land to any member they wish, and to appropriate land from any member for any reason. For instance, the Piikani Nation in Alberta retook the customarily held land of a band member

Ist (1980), 29 O.R. (2d) 24 (Co. Cl.).

l:s [1987] 4 C.N.I.R. 28 (Sask. Q.B.).

1: (1995), 144 N.S.R. (2d) 241 (C.A.).

1:3 Fraser Milner Casgrain, Federal Security Interests (Ottawa: Law Commission of Canada, 2000), online: Federal Security Interests <www.lec.gc.ca/en/themes/pr/cpra/fraser/fsi.asp>.

1:\% See Alcantara, supra note 44.

1: Flanagan \& Alcantara. supra note 5 at 500-501. 512 
in order to build a school. The land was centrally located and on a major road, making it easily accessible and convenient for all members to send their children there. ${ }^{130}$

Besides giving the band legal authority over all reserve land, the customary land tenure regime provides bands with the flexibility to develop their own land allotment, dispute resolution and appropriation regimes. This gives the band even greater authority to use the land for the collective benefit of the entire reserve. A band seeking to maximize the collective benefit of its land might structure its land administration as follows: At the top of the administration is the band council, which has ultimate authority over reserve land. Below it is a lands department made up of band civil servants and perhaps community members such as elders, with a clear mandate as to how land should be allotted, appropriated and administered. Also needed is a dispute resolution committee made up of councilors, lands department officials, elders and community members. This committee would forward its decisions to band council, which would then accept or reject it through a band council resolution. The band should make it clear that only band-recognized customary allotments will be recognized. The allotments themselves should make it clear that the allottee enjoys the land only at the pleasure of the band council, and that such allotments can be revoked at any time. Allotments should also be surveyed, recorded in a band registry and approved by band council resolution. All allotment records should be available for viewing by the public, and all band members should have access to the various committees where allotments are allotted and approved, and disputes resolved.

\section{B. INDIVIDUAL BAND MEMBERS}

For individual band members, on-reserve private property is meant to benefit individual holders with a secondary goal being the betterment of the band through the spinoff effects of their economic development projects. The ideal regime for accomplishing these goals is the certificate of possession (CP). Of the three regimes looked at in this paper, a CP provides the individual with the most security of tenure and land use options. A band member with a $\mathrm{CP}$ can farm his land, extract surface resources, build a house or business on it or lease it to a band or non-band member. The member also has incentives to invest on the reserve, knowing that the courts will protect him from unlawful intrusions by the Crown, band council and fellow band members. The spinoff benefits to the band depend on the success and type of project pursued. For instance, if a member builds a house on his land, the spinoff effect is that the band does not have to provide band housing to that member. Or, if a member starts a business on his land, then the spinoff effect might involve new jobs for fellow band members and an increase in the inflow of capital onto the reserve.

There are several means by which a member can structure his transactions to increase the efficiency by which he can achieve his goals. First, he should try to get band council approval for all transactions because their opposition can slow down an individual's use of the land. This was the case in Tsartlip, where despite the Indicu Act's lack of requirement of a band council approval for a s. 58(3) lease, the Court ruled that the Minister had to take into account the band's interests before approving such a lease. ${ }^{131}$ Second, the individual should 
ensure that all elements of the $\mathrm{CP}$ process are complete before using the land. This means that the member needs to ensure that the allotment is properly surveyed, approved by a valid band council resolution and by the Minister of Indian Affairs and recorded in the Lands registry.

However, most bands do not use CPs. Rather, most bands in Canada use customary rights. For the individual band member living on reserves that use customary rights, a number of things can be done to minimize band intrusions. First, the member should try to ensure that all of the elements of the allotment are clear and properly recorded. For instance, a record of the allotment should include an exact description or formal survey of the land being allotted, the length of the allotment and, if possible, the exact situations in which the band can take the land back from the allottee. The member should also try to get the band to agree to a specific form of compensation if or when the band retakes the land. This compensation should take into account any improvements that the allottee made to the land. Finally, the individual should push for a neutral dispute resolution mechanism that prevents nepotism from entering into any decisions. If the band proves uncooperative in accommodating some or any of these strategies, then the individual band member may have to obtain property offreserve.

\section{THE Crown}

The Crown has a twofold primary interest: to promote the economic and political selfsufficiency of bands while upholding its fiduciary duty to them. Customary rights seem to provide the most effective means for accomplishing this. As opposed to CPs, customary rights minimize the involvement of the federal government. Under a customary right regime each band is given responsibility over administering individual allotments. This allows bands to construct regimes tailored to their local customs, while creating procedures that allow it to use reserve land for the benefit of the entire reserve. $\mathrm{CPs}$, on the other hand, require the federal government to be heavily involved in the administration of individual allotments, restricting the ability of bands to govern according to local customs and needs.

In terms of structuring transactions to better accomplish its goals, the Crown might consider transferring the registration of CPs and other land allotments to local or band offices. It might also consider making greater use of the First Nations Land Management $A c t^{132}$ or ss. 53 and 60 of the Indian $A c t$, both of which allow the Crown to transfer some or all of its land management authority to individual bands. The strengths of ss. 53 and 60 are that (1) the Crown can transfer little or much power to a band depending on its abilities and needs, and (2) it retains the option of retaking its delegated authority at any time or for any reason, thus ensuring that it can perform its fiduciary duty as required. ${ }^{133}$

\section{Third Parties}

The primary interest of third parties such as banks is to finance on-reserve economic projects for the purpose of making money, whether through the interest from loans or funds

1.3 Supra note 44. 
collected on defaulted loans. Currently, bands and band members with interests in on-reserve property find it difficult to secure financing from off-reserve third parties. The main obstacles are ss. 29 and 89 of the Indian $A c t$, which prevent non-Indian parties from seizing Indian property. Sections 29 and 89 essentially make it impossible for Indian parties to put up Indian property as collateral for a loan.

There are ways to circumvent these restrictions. For instance, s. $89(1)$ of the Indian $\mathrm{ACt}$ allows leasehold interests to be used as collateral and seized by third parties in the event of a default. Section 89(2) allows for a seller of property sold under a conditional sales agreement (where the seller retains ownership over some part of the property sold) to recoup his property in the event of a default. Some First Nations have used ministerial and band guarantees to help members with individual interests acquire financing for building their own houses. For instance, the Six Nations band in Ontario allows members with good credit ratings and CPs to borrow money from a bank in return for ownership of the CP for the duration of the loan. In the event of a default, the band immediately pays off the loan to the bank and then either disposes of the property to another band member or keeps the land for band government purposes. If the member successfully pays off the loan, the band transfers the CP back to the individual member. ${ }^{114}$

For third parties such as off-reserve individuals looking to rent homes built on reserve land (such as at Westbank Nation in British Columbia) one major problem is the unpredictability of rent review clauses. At question in the Musqueam case and its related jurisprudence was the difficulty in assessing the value of reserve land due to the unique Indian features and legal environment of reserve land. ${ }^{13}$ "The Court found that an increase or decrease in the value of reserve land as compared to equivalent land found off reserve was to be applied depending on the particular reserve in question. This ruling has the potential of creating a chilling effect on the interest of third parties willing to invest or sign leases on reserves in Canada. Two options are available to these third parties. First, the obvious solution would be simply to add the term "leasehold" to "market value" or "current land value" to the rent review provision of leases, something which the Supreme Court of Canada has allowed for. However, it remains to be seen how a court will interpret such a provision in light of the Musqueam decision that the legal environment of a reserve has an effect on the value of leasehold reserve land. Second, the lessor and lessees might try to come to an agreement about a discount and have that discount included in the lease. The parties could agree to employ several assessors who would apply the principles of the Musqueam case to their assessments of the property. They could then try to determine a discount based on the unique features of the particular reserve and come to an agreement about the exact discount before signing the lease. The case law seems to suggest that this would be acceptable, although whether a court would accept this strategy remains in question.

\section{E. CONFIICT AMONG TIE: VARIOUS INTERESTS}

The Indian Act sets out a fundamental conflict between individual and collective interests on reserves in Canada. In essence, each band is given a choice. The default choice is 
collective rights where each band is legally responsible for all reserve land and has complete freedom to distribute land among its members in any way it sees fit. This is how most reserves in Canada operate. The other option is to have a mix of collective rights and certificates of possession (CPs), such as at Cowichan Tribes in British Columbia, or to completely adopt $\mathrm{CPs}$, as Six Nations in Ontario has done. ${ }^{136}$ The conflict comes when the collective interests of the band are at odds with the individual interests of a band member with some sort of on-reserve property right. For instance, at the Piikani reserve in Alberta, the band wanted to build a house on land to which a member had a customary right. The member did not want to give up his property and therefore sought legal advice. In line with the jurisprudence described above, his lawyer told him he had no legal recourse to stop the band from taking his land. ${ }^{137}$

Certificates of possession can also cause conflict between the collective and individual interests. At Westbank First Nation in British Columbia, much of the land is located near Kelowna, a popular tourist and retirement city. Despite the high value of this land, the band has been unable to reap many profits from it since most of it is held under $\mathrm{CP}$ by a small number of families. The result is a shortage of land and housing for the majority of the band's members, forcing them to live off-reserve. Moreover, these families have developed most of this land into housing lots leased to non-Indian residents. The security of these CPs and their concentration in the hands of a few families means that the band has been unable to reap any profits from the housing development. Moreover, they have been unable to retake the land to develop or redistribute it for the benefit of the entire reserve. ${ }^{138}$

This type of problem is not limited to bands that use CPs. At the Blood Tribe in Alberta, approximately 15 percent of the membership $(1,200$ members $)$ holds 75 perecent $(264,418$ acres) of the land under customary tenure. Because of the band's longstanding tradition of respecting customary allotments as legally binding contracts, the band council has been unable to retake and redistribute the land despite its legal power to do so. ${ }^{139}$

A second conflict inherent within the property rights regimes on reserves is the tension between the desire for greater band independence and the fiduciary duty of the Crown. All four actors see greater band independence from the Crown as a worthwhile goal. Bands want to be free of the Crown because they see the Crown's constant interference since before Confederation as one of the reasons for the current impoverished state of most reserves in Canada. ${ }^{140}$ Individual band members prefer greater band independence because dealing with a band's land administration department might be preferable to the long bureaucratic waits involved in getting CPs and leases surveyed, approved or registered by Indian Affairs and Northern Development. ${ }^{141}$ The Crown sees band independence as desirable since doing so reduces the amount of resources it must provide to bands. Finally, third parties may prefer

1'i. Supra note 6.

i' Flanagan \& Alcantara, supra nole 5 at 501.

itk lbid. al 512.

iii) Ibid. at 503.

1 t11 Canada, Royal Commission on Aboriginal Peoples, Report of the Royal Commission on Aboriginal People (Ottawa: Canada Communications Group Publishing. 1996).

it Supra note 44. 
band independence since it reduces the number of actors involved in economic development projects or leases.

However, the Crown's fiduciary duty can come into conflict with the goal of greater independence when corruption is involved. For instance, according to an anonymous observer, the Housing Department at Blood Tribe was closed from September 2001 to September 2002 due to the strong influence that chief and council had on which members were allotted housing or received repairs to their house. Conflict can also occur when individuals with $\mathrm{CPs}$ or third party individuals such as lessees want the federal government involved to protect their interests. For members with $\mathrm{CPs}$, it is preferable to make use of $s$. 58(3) leases through the Crown rather than the band since the case law above shows that the individual uses of land can sometimes come into conflict with band council desires. The potential problem of individual land use being detrimental to the band's collective interests is somewhat mitigated by the jurisprudence described above which requires the Minister of Indian Affairs to consider the band's position before agreeing to a s. 58(3) lease.

A final important tension is found between the desire to protect Aboriginal land and the need for economic development on reserves. As described above, ss. 29 and 89 prevent reserve land from being used as collateral for obtaining off-reserve financing for on-reserve economic development. This is a major constraint since, in essence, ss. 29 and 89 of the Indian Act limit on-reserve entrepreneurs to band or government financing, both of which are far more limited than the resources available through the private sector.

\section{F. RANKING ANd RECONCH.ING THE INTERESTS}

The main difficulty for lawmakers and adjudicators is how to rank and reconcile these competing interests. In the three conflicts described above, the law is clear. For collective and individual interests, collective interests (the band and band council) should prevail unless $\mathrm{CPs}$ are involved. If CPs are involved, then bands are limited in their ability to interfere with the activities of individual $\mathrm{CP}$ holders. To some extent, bands can interfere through bylaws of general application (such as zoning) under s. $81(1)(\mathrm{g})$ of the Indian Act. Moreover, the band can have some marginal influence should the $\mathrm{CP}$ holder seek to obtain a s. 58(3) lease, but this influence is limited to consideration by the Minister of Indian Affairs and nothing more.

In terms of the second conflict, the fiduciary duty of the Crown only comes into play when there are disagreements between band councils and band members over CP-held land. In those cases, the Crown has very few direct mechanisms for interference. It can apply pressure through the purse or through its approval power for certain types of leases and $\mathrm{CP}$ transactions. Collective tenure, on the other hand, provides a powerful inechanism for bands to accomplish their desired goals.

In terms of the final conflict, the law states that ss. 29 and 89 prevent off-reserve third parties from seizing indian land. Some bands have been able to get around this by using band or ministerial guarantees, but the impact of these measures has been limited to those bands that have the financial capability to cover the costs of defaulted loans. For most bands, the 
inability to put up Indian property as collateral has prevented members from engaging in economic development or housing projects on reserve.

The law is clear on how these competing interests should be ranked and reconciled. However, a large body of scholarship with normative implications has emerged that suggests that the law might consider changing the way it ranks and reconciles these interests. This body of scholarship argues that the overarching goal for all actors involved in the administration of Canadian Indian reserves is to foster each band's political and economic independence and reduce their dependence on the federal government. The disagreement within the scholarship revolves around different approaches for accomplishing this goal. The main fault line between these two approaches revolves around the emphasis they each place on the collective and individual interests of the band. ${ }^{1.2}$

The first approach involves strengthening the powers of the band so that it can act effectively in the interests of the entire band. Under this approach, the First Nations Land Management $A c t$, individual self-government agreements and ss. 53 and 60 of the Indian Act are the key mechanisıns for increasing the involvement of individual bands in the administration of their land. Under these mechanisms, bands are given responsibility over the administration of all aspects of their band's land management, including surveys, allotment approval procedures, legal and historical research, administration of leases and record keeping. In conjunction, stable government funding, at least in the short-term, would also be provided to help bands establish and maintain a competent lands department.

The second approach focuses on strengthening and improving the individual property rights of band members. Within this paradigm, the key to prosperity is increasing the security of tenure of individual property rights and allowing these rights to be used to obtain offreserve financing for on-reserve economic development projects. For instance, one of the main problems with collective rights is that they lack sufficient security of tenure. Band members know that the band can at any time step in and take customarily held land for any reason. The lack of security of tenure acts as a disincentive for investing on reserves as band members who build a house, business or other improvement on customarily held land face the possibility of losing their land without compensation. The law can strengthen the security of tenure of customary rights by recognizing and enforcing customarily held land that is properly surveyed, allotted and recorded in a legally binding contract between the allottee and the band. In terms of using Indian land as security for a loan, the law could allow other innovative techniques to be used to increase off-reserve financing for on-reserve projects. At Six Nations in Ontario, the band acts as a guarantor. At other First Nations, the Minister of Indian Affairs acts as the guarantor. The Mohawks of Kahnawake use an Indian trustee to act as a guarantor for members seeking to use their land to secure off-reserve financing.

\section{Concidision}

The way in which the courts have treated individual property rights on reserves has had a significant impact on Indian reserves in Canada. The fact that customary allotments are

11: Supra notes 1. 140; and Tom Flanagan, First Nations? Second Thoughts (Montreal: MeGill-Queen's Universily P'ress, 2000). 
only enforceable if they resemble incomplete CPs is a problem because many bands have customary holdings that do not resemble CPs. Thus most customary allotments on reserves provide very little security of tenure as the courts will not enforce them. Without the protection of the courts, band councils have the power to step in and retake customarily held land at any time. In addition, band councils are also responsible for dispute resolution, thereby creating another opportunity for politics to intrude. Without security of tenure the entrepreneurial spirit of a member is sapped. A member could use a large portion of his savings to build a relatively expensive house on custonarily heid land only to have the band repossess the land, forcing the member to either move the house off of the land or abandon it.

According to one First Nation housing manager in western Canada (who wishes to remain anonymous), it is even disputable whether the member would be able to move the house off of the land since one view holds that once foundations are placed, the house becomes attached to the land and becomes a part of the reserve. Therefore, for reserves with customary land tenure, members may choose to build off reserve since such property is insulated from band politics and is protected by the courts.

Court decisions can have a negative effect on $\mathrm{CP}$-held land as well. By requiring all $\mathrm{CP}$ transactions to have the consent of the band council and approval of the Minister, a significant time cost can be inflicted on the holder. A typical allotment or transfer is supposed to take somewhere between six months to a year. However, according to band officials at $\mathrm{Six}$ Nations, it can take anywhere from a year to 11 years to complete! $!^{141}$ This time delay can inflict serious costs including preventing a member from obtaining financing to develop the land or delaying the start date for constructing a house or a business on the land.

Another problem generated from the CP case law relates to the security of tenure that CPs provide. On some reserves a majority of the land is held under $C P$ by a small number of band members. The result is a severe shortage of land in which members are forced to live in subdivisions on reserve or forced to move off reserve. The security of tenure that CPS provide prevents the band from redistributing land in a more equitable manner and from using all of the land for the benefit of the entire band. For instance, at Westbank First Nation. British Columbia, several families hold most of the land under $C P$ and have developed their land into residential neighbourhoods for middle class and wealthy off-reserve residents to lease. The band reaps none of these revenues and is unable to provide land to its members since it cannot repossess CP-held land. Furthermore, band members cannot lease land from the $\mathrm{CP}$ holders since most of the members do not have the financial capability to do so. ${ }^{1+1}$

The Musqueam decision has created a cloud of uncertainty for bands and potential investors. The decision may make it difficult for bands and customers to invest in on-reserve projects when they do not know what the impact of the legal environinent of a particular reserve will be on the value of their investment. Coupled with the fact that valuing land is an imprecise and subjective science, this decision may induce a chilling effect on on-reserve economic development. During the proceedings in the Musqueam case, the plight of the 
lessees was widely publicized, generating much sympathy towards them. Soon after the case was decided, some bands, such as Westbank First Nation, experienced a drop in the number of inquiries regarding leasing reserve land. Since then, conditions have improved, although some investors remain wary. ${ }^{145}$ The obvious solution would be simply to add the term "leasehold" to "market value" or "current land value" to the rent review provision of leases, something which the Supreme Court has allowed for. However, it remains to be seen how a court will interpret such a provision in light of the Musqueam decision that the legal environment of a reserve has an effect on the value of leasehold reserve land.

Further research on the effects of these three property right regimes on Canadian Indian reserves needs to be done. One area in particular requires special attention: the division of matrimonial property after marital breakdown. In essence, the Indian Act prevents the courts from dividing or awarding an interest in matrimonial property to a spouse whose name does not appear on the ownership papers. The courts have found a way to award financial compensation in lieu of granting ownership. However, since much of the individual property on reserves is held solely by men, women and their children are usually forced to move off reserve since available land and housing on reserves tends to be scarce. Further research needs to determine the number of individuals affected by this problem and to generate proposals for correcting it. ${ }^{146}$

las Ibid.

18f. Canada, Senate, Standing Senate Committee on Human Rights, "A Hard Bed to Lie In: Matrimonial Real Property on Reserve" ( November 2003), online: Parliament of Canada <www.parl.gc.ca/37/2/parlbus/commbuc/senate/com-e/huma-e/10app2-e.pdf?Language=E\&Parl= $37 \& S c s=2 \& c o m m \_i d=77$; Canada. Indian and Northern Affairs Canada, Affer Marriage Breakdown: Information on the On-Reserve Matrimonial Home (Ottawa: Minister of Public Works and Government Services Canada, 2003), online: Indian and Northern Affairs Canada <ww.ainc-inac.gc.ca pr/pub/mpr/mprpdf_c.pdf>: W. Comet \& A. Lendor, "Discussion Paper: Matrimonial Real Property on Reserve" (Ottawa: Department of Indian and Northern Affairs, 2002), online: Indian and Northern Aflairs Canada < mnw.ainc-inac.ge.ca/pr/pub/matr/index_e.html >: Karen Abbott, "Urban Aboriginal Women in British Columbia and the Impacts of the Matrimonial Real Property Regime" (Ottawa: Department of Indian and Northern Affairs Canada. 2003) at 3-4. 14-15. online: Indian and Northern Afrairs Canada <uww.ainc-inac.gc.ca/wige/ura/index_e.html>; Alcantara, "Indian Women." supra note 117. 